\title{
FLOOD-RISK MAPPING FOR SEA-LEVEL RISE AND EXTREME WAVE EVENTS USING BATHYMETRIC AND TOPOGRAPHIC LIDAR WITHIN THE BASQUE COAST
}

\author{
Guillem Chust, AZTI-Tecnalia, Marine Research Division. Txatxarramendi ugartea z/g; 48395 \\ Sukarrieta, Spain, gchust@azti.es \\ Pedro Liria, AZTI-Tecnalia, email: pliria@azti.es \\ Ainhoa Caballero, AZTI-Tecnalia, email: acaballero@azti.es \\ Marta Marcos, IMEDEA (CSIC-UIB), Miquel Marquès, 07190 Esporles, Spain, email: \\ marta.marcos@uib.es \\ Ángel Borja, AZTI-Tecnalia, email: aborja@azti.es
}

\begin{abstract}
The mean sea level in the Bay of Biscay is expected to rise between 29 and $49 \mathrm{~cm}$ from 2001 to 2099, as a result of regional thermal expansion and global ice-melting. The objective of this contribution is to assess the impacts of the future projected sea level rise (SLR) in the Bay of Biscay and extreme wave events on Basque coastal habitats (saltmarshes, sandy beaches and dunes, estuaries and urban areas) by generating flood risk maps within the Basque coast (Gipuzkoan coast and the Oka estuary). A flood-risk map has been generated by delimiting the SLR projected (i.e., $49 \mathrm{~cm}$ ) over a high-resolution Digital Elevation Model (DEM). This DTM has been extracted from airborne laser altimetry data (topographic and bathymetric LiDAR). Also, the risk of flood during storm-surge events has been calculated, by combining the action from tidal level (as the sum of the astronomic tide component and the meteorological conditions) and run-up. The impacts on land use and biological communities have been assessed, by overlaying the flood risk maps and a coastal habitat classification. The results indicate that sea level rise and extreme waves predicted with a 50-yr return period will affect 110.8 ha and 164.1 ha, respectively, of the supralittoral area of the Gipuzkoan coast by the end of the 21 st century. The impacted areas by sea level rise are concentrated over low-lying areas within the inner estuaries, with terrestrial and artificial habitats being the most affected. Sandy beaches are expected to undergo mean shoreline retreats of between $25 \%$ and $40 \%$, of their width. The Oka estuary is expected to be affected by 12 ha by the sea level rise. The extreme waves predicted with a 50 -yr return period will affect mainly sandy beaches, harbours and urban areas exposed to high wave energy (NW orientation). The risk assessment of the areas, coastal land uses and habitats that will be affected is potentially useful for local management, in order to adopt adaptation measures to the SLR and extreme wave events induced by the global climate change.
\end{abstract}

Keywords: flood risk, extreme wave, sea level, climate change, Basque, coast

\section{Introduction}

Several studies, within the southern Bay of Biscay, have identified a sea level rise (SLR) during the second half of the 20th century (Marcos et al., 2005). An analysis of sea level records from the tide gauge of Santander, located in the SE Bay of Biscay, has revealed that

This is an Open Access article distributed under the terms of the Creative Commons Attribution-Noncommercial License 3.0, which permits unrestricted use, distribution, and reproduction in any noncommercial medium, provided the original work is properly cited. 
relative mean sea-level has been rising at a rate of $2.08 \pm 0.33 \mathrm{~m} \mathrm{~m} \mathrm{yr}-1$, from 1943 to 2004 (Chust et al., 2009); this is consistent with sea-level trends from other tide-gauge measurements within the area and with previous results obtained in the Bay of Biscay (Marcos et al., 2005). The mean sea level in the bay is expected to rise between 29 and 49 $\mathrm{cm}$ from 2001 to 2099, as estimated from Atmosphere-Ocean Coupled General Climate Models (AOGCMs) outputs as a result of regional thermal expansion and global ice-melting (Chust et al., 2010). The objective of this contribution is to assess the impacts of the future projected SLR and extreme wave events on Basque coastal habitats (saltmarshes, sandy beaches and dunes, estuaries and urban areas) by generating flood risk maps within the Gipuzkoan coast and the Oka estuary (Basque coast, northern Spain, south-eastern Bay of Biscay.

\section{Data sets: LiDAR-based DTM and habitat classification}

The Digital Elevation Model (DEM) of Gipuzkoa (available from http://b5m.gipuzkoa.net/web5000/) was extracted using airborne topographic LiDAR (Chust et al., 2010). It has a vertical accuracy of $0.15 \mathrm{~m} \mathrm{RMS}$, in low vegetated and low slope areas, and $1 \mathrm{~m} \times 1 \mathrm{~m}$ spatial resolution. The DEM of Oka estuary was extracted using a bathymetric LiDAR (Chust et al., In press) of $2 \times 2 \mathrm{~m}$ spatial resolution. A classification of nine coastal and estuarine habitats (sandy beaches and muds, vegetated dunes, shingle beaches, sea cliffs and supralittoral rock, wetlands and saltmarshes, terrestrial habitats, artificial land, piers, and water surfaces) was undertaken by photointerpretation of the colour aerial photographies, acquired in 2004 and 2005.

\section{Flood risk mapping}

The flood level (FL) is defined as the joint action of the tide level (TL) and the wave run-up $(R U)$. The tide level, in turn, encompasses the astronomic tide (AT), due exclusively by the gravitational attraction and the movement of astronomical objects, and the meteorological tide (MT), which are the variation on sea level due to meteorological conditions (i.e., atmospheric pressure, wind). Wave run-up is the vertical extent of wave uprush on a beach or structure above the still water level. Thus, FL is defined as follows:

$$
F L=T L \square R U=A T \square M T \square R U
$$

To obtain the flood level along the coast, the software Coastal Modelling System (SMC) (SMC, 2002) was used. First, SMC was used to obtain the sea level and offshore wave conditions with a joint probability of occurrence associated to a return period of 50 years. This estimation is based on extreme regime analysis of data from the Bilbao tide gauge and Bilbao Vizcaya buoy (Puertos del Estado; URL: http://www.puertos.es/). The conditions obtained were: Sea level of 2,4 $\mathrm{m}$; offshore $\mathrm{Hs}=10 \mathrm{~m}$. The peak period $\left(\mathrm{T}_{\mathrm{P}}\right)$ associated to the selected Hs was obtained followina the ROM (maritime construction recomendations) 0,3-91, where for the Bilbao buoy: $T p=7 \overline{H s} ; T p \leq 20 \mathrm{seg}$.

Extreme wave conditions along the coast were simulated using MOPLA, which is an intermediate to shallow water spectral wave propagation model, integrated within the SMC software. High resolution multibeam bathymetric data were introduced on the model to obtain the extreme wave characteristics along the coastline. The coastline of Gipuzkoa has been sectorized and the extreme wave run-up has been calculated on a discrete number of 
representative profiles as follows. The run-up (RU) is calculated by multiplying the theoretical run-up $\mathrm{RU}_{0}$, which assumes the mean slope of the breaking waves as an undefined slope (Nielsen and Hanslow, 1991), by a set of morphological coefficients:

$$
R U=R U_{o} \gamma_{b}\left\ulcorner\gamma _ { f } \left\lceil\gamma_{w}\right.\right.
$$

where $\gamma_{b}=\frac{\tan \beta}{\tan \alpha}, \beta$ is the slope of the supralittoral fringe, $\alpha$ is the slope of the breaking zone), $\gamma_{f}$ and $\gamma_{w}$ are the rugousity coefficient and percolation coefficient, respectively. RUo is estimated following Nielsen and Hanslow (1991).

The integration of the extreme wave flood level along the coast has been crossed with a detailed the DTM to obtain the flood risk map. The computed flood level of extreme waves expected for a 50-yr return period was compared with the scenario of mean sea level rise expected by the end of the $21^{\text {st }}$ Century (i.e. $49 \mathrm{~cm}$; Chust et al., 2010). The increase of extreme Hs by 2050 is $3 \mathrm{~cm}$ according to Universidad de Cantabria (2007), hence, it is negligible compared with the mean extreme wave along the coast $(8.17 \mathrm{~m})$.

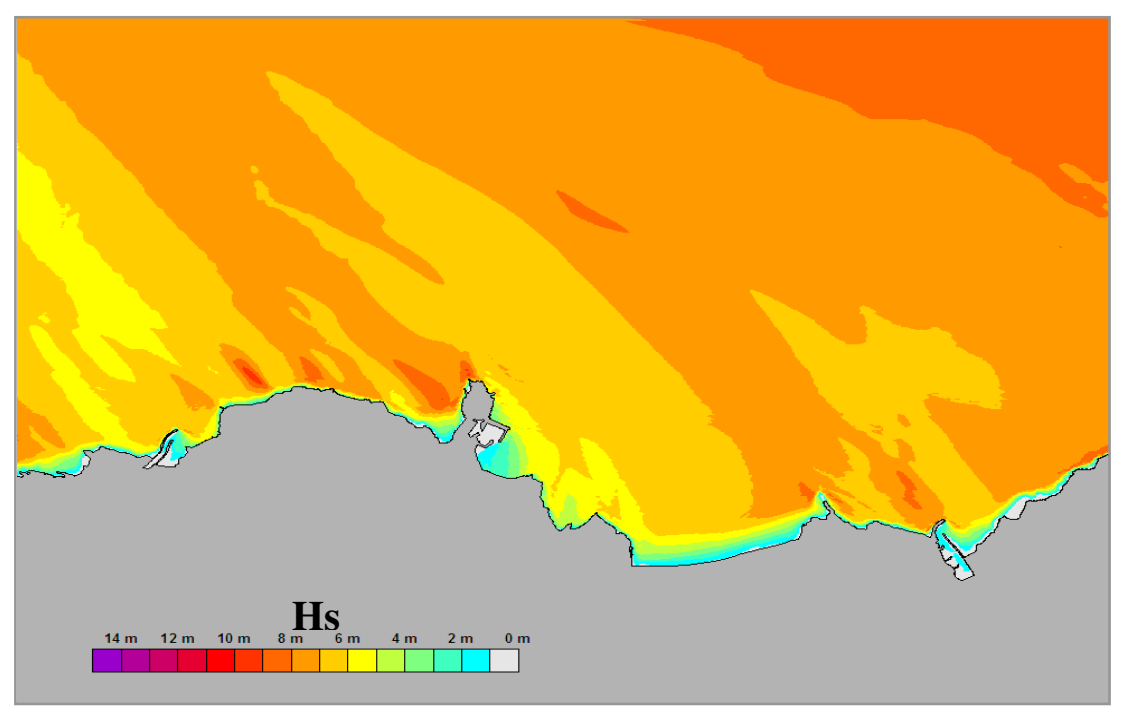

Fig. 1. Hs obtained for a coastal detail (Zumaia-Orio) using $T p=20$ seg and present conditions (tide level=2,4 $\mathrm{m}$ referred to $M S L$ in Alicante).

\section{Results}

Fig. 2 shows the distribution of the extreme wave flood level along a series of coastal profiles defined for the computation. The application of the extreme wave flood level to the highresolution LiDAR DTM produced the flood risk map (Fig. 3). This map indicates that 164.1 ha are identified as vulnerable to extreme waves. The relative effects by habitats are shown in Table 1 and compared with the effects of the sea level rise obtained by Chust et al. (2010). The effect of the extreme wave run-up will affect especially within the coastline (mainly affecting sandy and shingle beaches, dunes, artificial land and supralittoral rock); whilst the 
effect of sea level rise will be concentrated over low-lying areas within the inner estuaries, with terrestrial, wetlands and salt-marshes and artificial habitats being the most affected.

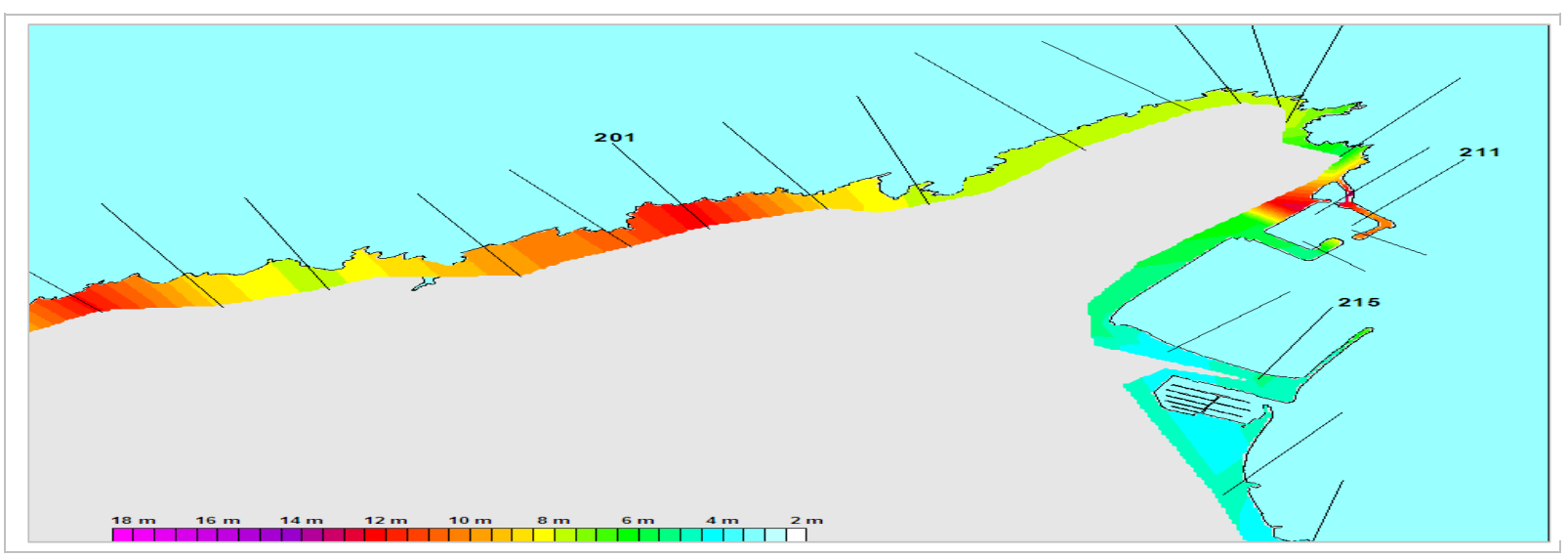

Fig. 2. Extreme wave flood level at the coastline expected for a 50-yr return period in the coastal area of Hondarribi (Gipuzkoa).

Table 1. Flooded area for each habitat of the Gipuzkoan coast estimated for 2099, with respect to 2001, under the maximum projected sea level rise of $49 \mathrm{~cm}$ (SRES A1B) and by extreme waves. Key: na not accounted for, applied to those habitats not restricted to the coast such as artificial land, terrestrial habitats and water surfaces.

\begin{tabular}{lcccccc}
\hline HABITAT & $\begin{array}{c}\text { Total } \\
\text { area in } \\
\text { Gipuzkoa } \\
\text { (ha) }\end{array}$ & $\begin{array}{c}\text { Slope } \\
\text { () }\end{array}$ & $\begin{array}{c}\text { Flood } \\
\text { area } \\
\text { (ha) by } \\
\text { SLR }\end{array}$ & $\begin{array}{c}\text { Flood } \\
\text { area (\%) } \\
\text { by SLR }\end{array}$ & $\begin{array}{c}\text { Flood } \\
\text { area } \\
\text { (ha) by } \\
\text { extreme } \\
\text { wave }\end{array}$ & $\begin{array}{c}\text { Flood } \\
\text { area } \\
\text { (\%) by } \\
\text { extreme } \\
\text { wave }\end{array}$ \\
\hline Sandy beaches and muds & 68.6 & 3.6 & 10.1 & 14.7 & 36.8 & 53.7 \\
Vegetated dunes & 15.3 & 4.1 & 2.3 & 14.9 & 4.5 & 29.6 \\
Shingle beaches & 12.0 & 11.8 & 0.8 & 6.8 & 5.2 & 43.6 \\
Sea cliffs and supralittoral rock & 141.4 & 17.0 & 7.3 & 5.2 & 54.0 & 38.2 \\
Wetlands and saltmarshes & 60.4 & 5.4 & 3.9 & 6.5 & 0.2 & 0.3 \\
Terrestrial habitats & na & 5.8 & 45.5 & na & 5.7 & na \\
Artificial land (excluding piers) & na & 9.6 & 34.4 & na & 52.0 & na \\
Piers & 17.6 & - & 0.8 & 4.6 & 5.5 & 31.2 \\
River water surfaces & na & - & 5.7 & na & 0.2 & na \\
\hline TOTAL & & & $\mathbf{1 1 0 . 8}$ & & $\mathbf{1 6 4 . 1}$ & \\
\hline
\end{tabular}



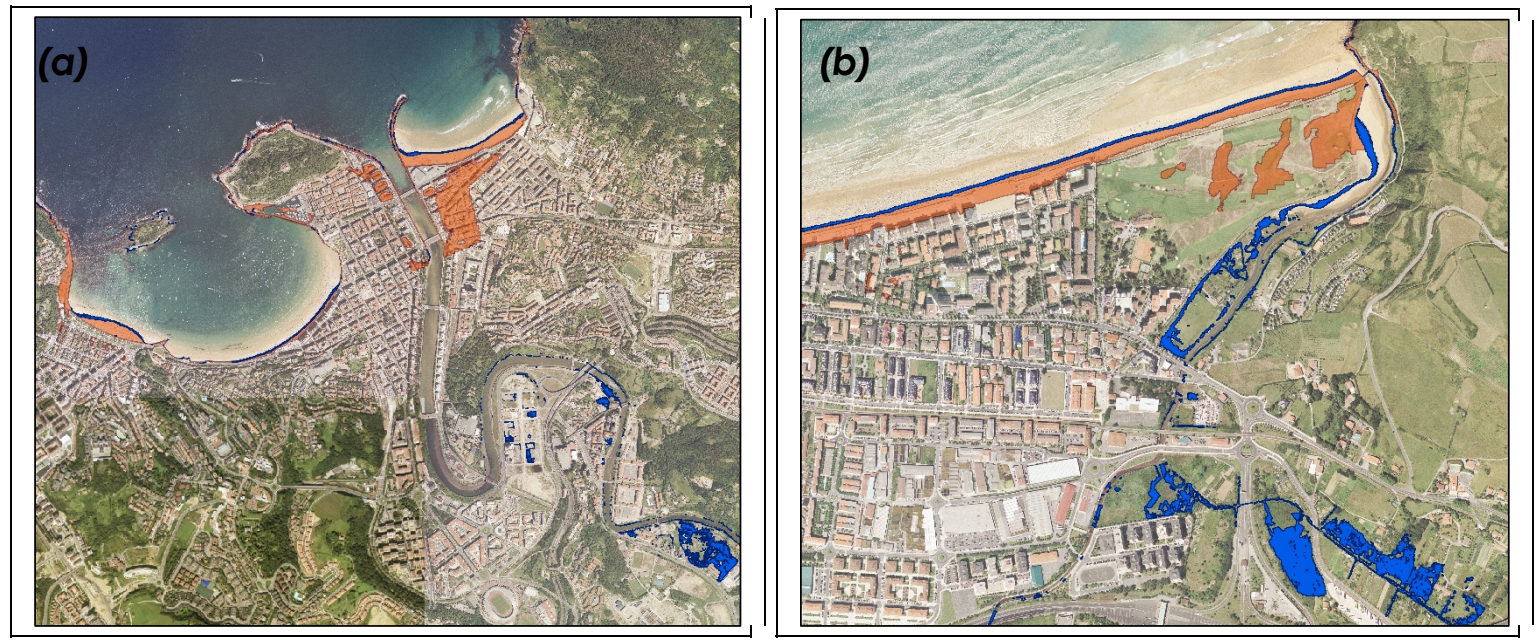

Fig. 3. Flooded area in different locations of the Gipuzkoan coast projected by 50-yr return period of extreme wave (red area) and by $49 \mathrm{~cm}$ sea level rise by 2099 (blue area): a) Donostia-San Sebastián, b) Zarautz.

Within the Oka estuary, the SLR is expected to affect 12 ha, being sandy beaches (4,6 ha) the most affected habitat, followed by salt-marshes (1,9 ha) and vegetated dunes (1,4 ha).

\section{Conclusions}

The impacts of sea level rise and extreme waves predicted with a 50-yr return period indicate that 110.8 ha and 164.1 ha, respectively, of the supralittoral area of the Gipuzkoan coast will be affected by the end of the 21st century. The impacted areas by sea level rise are concentrated over low-lying areas within the inner estuaries, with terrestrial and artificial habitats being the most affected. Sandy beaches are expected to undergo mean shoreline retreats of between $25 \%$ and $40 \%$, of their width. The Oka estuary is expected to be affected by 12 ha by the sea level rise. The extreme waves predicted with a 50 -yr return period will affect mainly sandy beaches, harbours and urban areas exposed to high wave energy (NW orientation). The risk assessment of the areas, coastal land uses and habitats that will be affected is potentially useful for local management, in order to adopt adaptation measures to the SLR and extreme wave events induced by the global climate change.

\section{References}

Chust G, Borja Á, Liria P, Galparsoro I, Marcos M, Caballero A, Castro R (2009) Human impacts overwhelm the effects of sea-level rise on Basque coastal habitats ( $N$ Spain) between 1954 and 2004. Est Coast Shelf Sci 84:453-462.

Chust G, Caballero A, Marcos M, Liria P, Hernández C, Borja Á (2010) Regional scenarios of sea level rise and impacts on Basque (Bay of Biscay) coastal habitats, throughout the 21st century. Est Coast Shelf Sci 87:113-124.

Chust, G., Grande, M., Galparsoro, I., Uriarte, A. \& Borja, A. Capabilities of the bathymetric Hawk Eye LiDAR for coastal habitat mapping: a case study within a Basque estuary. Estuarine, Coastal and Shelf Science (In press). doi: DOI: 10.1016/j.ecss.2010.07.002. 
Marcos M, Gomis D, Monserrat S, Álvarez-Fanjul E, Pérez B, García-Lafuente J (2005) Consistency of long sea-level time series in the northern coast of Spain. J Geophys Res 110: C03008.

Nielsen, P. and D.J. Hanslow (1991). Wave run-up distributions on natural beaches. Journal of Coastal Research. Vol. 7, № 4, pp. 1139-1152.

SMC (2002) Ministerio de Medio Ambiente (Dirección General de Costas) y Grupo de Ingeniería Oceanografica y de Costas (G.I.O.C.) de la Universidad de Cantabria.

Universidad de Cantabria 2007. Atlas de inundación del litoral peninsular español.

\section{Acknowledgements}

This project is supported by the Department of Environment and Regional Planning and by the Industry, Trade and Tourism Department of the Basque Government (K-Egokitzen II project, Etortek Funding Program), and by the Ministry of Environment and Rural and Marine Environment of the Spanish Government (Project Ref.: 0.39/SGTB/2007/4.1). 